\title{
DeepNEU: a machine learning platform for simulating Cytokine Storm and Coagulopathy that complicate severe COVID-19 to enable targeted drug repurposing
}

Sally Esmail PhD

123Genetix Inc.

Wayne R Danter MD ( $\square$ wdanter@123Genetix.com )

123Genetix Inc.

\section{Research Article}

Keywords: Machine Learning, SARS-CoV-2, COVID-19, Cytokine Storm, Coagulopathy

Posted Date: May 5th, 2021

DOI: https://doi.org/10.21203/rs.3.rs-484061/v1

License: (c) (1) This work is licensed under a Creative Commons Attribution 4.0 International License.

Read Full License 


\section{Abstract}

COVID-19 is a disease that results from infection with the SARS-CoV-2 virus. The disease is often complicated by cytokine storm and/or a coagulopathy These two complications appear to be responsible for much of the increased mortality seen in severe COVID-19. While available treatment options including systemic corticosteroids and heparin have been beneficial in some ventilator dependent patients, mortality rates remain excessive. Several clinical trials using previously approved drugs and drug combinations are urgently underway to improve the current situation. The primary purpose of this project was to evaluate the DeepNEU stem-cell simulation platform by creating and validating computer simulations of artificial lung cells infected with SARS-CoV-2 to enable rapid identification of therapeutic targets and drug repurposing for specifically treating both the cytokine storm and coagulopathy associated with severe COVID-19. The data generated from this project confirm that (1) COVID-19 can be simulated in human alveolar type lung cells infected with SARS-CoV-2, (2) these simulated lung cells can develop features of the cytokine storm and coagulopathy that often complicate severe COVID-19, (3) the unsupervised machine learning system performed well in all COVID-19 simulations based on available published wet lab data and (4) the platform successfully identified potentially effective double drug combinations for both COVID-19 associated cytokine storm and coagulopathy for urgent clinical study. We conclude that while DeepNEU (v5.0) requires further validation, it is very likely that the most important application of this machine learning platform will be to improve our preparedness for serious future viral outbreaks and their life-threatening complications.

\section{Introduction}

As of this writing Coronavirus disease (COVID-19) resulting from SARS-COV-2 virus infection has caused a worldwide pandemic, with $>3,000,000$ deaths and $\sim 150,000,000$ cases reported internationally(1). While the SARS-CoV-2 virus does have some similarities to the SARS virus of 2003, unfortunately SARS-CoV-2 represents a novel viral pathogen to the human hosts (2). Extensive efforts have resulted in effective vaccines and some antiviral therapies. However, vaccine development, testing and approval to combat emerging resistant strains across the globe will require ongoing efforts. Amongst the symptomatic patients with COVID-19 most will experience a mild respiratory tract infection, but some patients progress to more critical illness that may be characterized by cytokine storm, hyperactive immune response, and coagulopathy $(3,4)$. Both cytokine storm and coagulopathy are associated with an increased risk of death $(3,4)$.

Cytokine storm is characterized by an elevation of cytokines including several interleukins, interferons and tumor-necrosis factors (5). The excessive release of these immune mediators is injurious to host cells (6). In addition, the importance of COVID-19 associated coagulation abnormalities is becoming increasingly clear in that a significant proportion of patients with severe COVID-19 develop potentially lethal venous and arterial thromboembolic complications which sometimes go unrecognized (7).

The cytokine storm induced by SARS-Cov-2 infection 
SARS-CoV-2 infection is often associated with acute lung injury (ALI), systemic inflammatory response syndrome (SIRS), and acute respiratory distress syndrome (ARDS) (8). Patients with severe COVID-19 showed significant increases in cytokines such as IL-2, IL-6, IL-7, IL-10, GSCF, IFNY, IP10, MCP-1, MIP1A and TNF-a, with the characteristic features of a cytokine storm (9). Normally, when a virus infects the body, the inflammatory response plays an important antiviral role, but when the anti-SARS-CoV2 inflammatory response is uncontrolled the resultant cytokine storm can be very damaging to tissues and organs in affected patients (10). Therefore, developing strategies for effectively suppressing cytokine storm is essential for limiting disease progression and reducing the mortality rate in patients with COVID19.

\section{The coagulopathy induced by SARS-Cov-2 infection}

It has been reported that the pathology of the lungs in some patient with severe COVID-19 shows marked microvascular thrombosis and hemorrhage associated with extensive alveolar and interstitial inflammation and diffuse intravascular pulmonary coagulopathy (11). Patients at this phase of disease progression sometimes develop a hypercoagulable state and D-Dimer-based coagulation factors may be abnormal. At a more advanced stage of disease progression, D-dimer is significantly increased, along with a prolonged prothrombin time (PT) and gradual decreases of fibrinogen (FBG) and platelet count $(12,13)$. It is also believed that COVID-19 can activate the coagulation cascade through various mechanisms, leading to severe hypercoagulability (14). Therefore, in addition to all necessary respiratory support and mitigating cytokine storm, the timely identification and treatment of coagulopathy is also crucial.

\section{The DeepNEU machine learning platform for identifying therapeutic targets for severe COVID-19}

The DeepNEU platform is a validated hybrid deep-machine learning system with elements of fully connected recurrent neural networks (RNN), cognitive maps (CM), Support Vector Machines (SVM) and evolutionary systems (GA). Recently, DeepNEU (v5.0) has been used to simulate artificially induced wild type and SARS-CoV2 infected Type 1 (AT1) and Type 2 (AT2) alveolar lung cells (aiLUNG and aiLUNGCOVID-19 respectively) derived from artificially induced human pluripotent stem cells (aiPSC)(15).

The primary purpose of the current research project was to evaluate the DeepNEU stem-cell simulation platform by creating and validating computer simulations of artificial AT1 and AT2 lung cells infected with SARS-CoV-2 to enable the rapid identification of therapeutic targets and drug repurposing for specifically treating both the cytokine storm and coagulopathy associated with severe COVID-19.

\section{Methods}

The DeepNEU platform is a literature validated hybrid deep-machine learning system with elements of fully connected recurrent neural networks (RNN), cognitive maps (CM) support vector machines (SVM) and evolutionary systems (GA). The detailed methodology for simulation development and validation 
plus the description of the current database (DeepNEU v5.0) used in these experiments has been previously described in detail (15-17).

\section{The DeepNEU simulations}

The main goal of this project was to extend our previous research into SARS-CoV-2 lung infection by evaluating a rationally defined set of repurposed drugs and their combinations for the treatment of the cytokine storm and coagulopathy that often complicates this viral infection. As described previously (15),we first created computer simulations (aiPSC) of human induced pluripotent stem cells (iPSC) and lung (aiLUNG) cells. Once validated with published peer reviewed data, the aiLUNG simulations were exposed to simulated SARS-CoV-2 infection by turning on extracellular Spike-RBP (RNA Binding Domain) in the presence of active Transmembrane Serine Protease 2 (TMPRSS2). Finally, several potential factor and combination of factor inhibitors were evaluated regarding their ability to ameliorate known features of the cytokine storm and coagulopathy often seen with severe COVID-19. A summary of the 17 single known drug simulations evaluated in the initial experiments are presented in Table 1 and the final 15 known two drug combinations evaluated are summarized in Table 2. The same single and two drug combinations outlined below were applied to both the Cytokine Storm and Coagulopathy.

\section{Table 1: Summary of evaluated single drug simulations}




\begin{tabular}{|c|c|c|}
\hline Model & Status & Recipe \\
\hline aiPSC-WT & Pluripotent Uninfected & Fibroblast + OKSM + Dox \\
\hline aiLUNG (i.e. Wild Type) & Differentiated Uninfected & $\begin{array}{l}\text { aiPSC + NKX-2.1 + WNT5a + LUNG } \\
\text { medium }\end{array}$ \\
\hline aiLUNG + SARS-CoV-2 & $\begin{array}{l}\text { Differentiated Infected and } \\
\text { Untreated }\end{array}$ & $\begin{array}{l}\text { aiLUNG + initial viremia + active } \\
\text { TMPRSS2 }\end{array}$ \\
\hline $\begin{array}{l}\text { aiLUNG + SARS-CoV-2 + } \\
\text { IL-1a+1b inhibitor }\end{array}$ & $\begin{array}{l}\text { Differentiated Infected and } \\
\text { Treated ( } 1 \text { drug) }\end{array}$ & $\begin{array}{l}\text { aiLUNG + viremia + active TMPRSS } 2+ \\
\text { IL-1a+1b inhibitor }\end{array}$ \\
\hline $\begin{array}{l}\text { aiLUNG + SARS-CoV-2 + } \\
\text { IL-6 inhibitor }\end{array}$ & $\begin{array}{l}\text { Differentiated Infected and } \\
\text { Treated (1 drug) }\end{array}$ & $\begin{array}{l}\text { aiLUNG + viremia + active TMPRSS2 + } \\
\text { IL-6 inhibitor }\end{array}$ \\
\hline $\begin{array}{l}\text { aiLUNG + SARS-CoV-2 + } \\
\text { TNFa Inhibitor }\end{array}$ & $\begin{array}{l}\text { Differentiated Infected and } \\
\text { Treated ( } 1 \text { drug) }\end{array}$ & $\begin{array}{l}\text { aiLUNG + viremia + active TMPRSS2 + } \\
\text { TNFa Inhibitor }\end{array}$ \\
\hline $\begin{array}{l}\text { aiLUNG + SARS-CoV-2 + } \\
\text { COX2 Inhibitor }\end{array}$ & $\begin{array}{l}\text { Differentiated Infected and } \\
\text { Treated ( } 1 \text { drug) }\end{array}$ & $\begin{array}{l}\text { aiLUNG + viremia + active TMPRSS2 + } \\
\text { COX2 Inhibitor }\end{array}$ \\
\hline $\begin{array}{l}\text { aiLUNG + SARS-CoV-2 + } \\
\text { HCQ }\end{array}$ & $\begin{array}{l}\text { Differentiated Infected and } \\
\text { Treated ( } 1 \text { drug) }\end{array}$ & $\begin{array}{l}\text { aiLUNG + viremia + active TMPRSS2 + } \\
\text { HCQ }\end{array}$ \\
\hline $\begin{array}{l}\text { aiLUNG + SARS-CoV-2 + IFN } \\
\text { a+b Inhibitor }\end{array}$ & $\begin{array}{l}\text { Differentiated Infected and } \\
\text { Treated ( } 1 \text { drug) }\end{array}$ & $\begin{array}{l}\text { aiLUNG + viremia + active TMPRSS2 + } \\
\text { IFN } \mathbf{a}+\mathbf{b} \text { Inhibitor }\end{array}$ \\
\hline $\begin{array}{l}\text { aiLUNG + SARS-CoV-2 + } \\
\text { TMPRSS2 Inhibitor }\end{array}$ & $\begin{array}{l}\text { Differentiated Infected and } \\
\text { Treated ( } 1 \text { drug) }\end{array}$ & $\begin{array}{l}\text { aiLUNG + viremia + active TMPRSS2 + } \\
\text { TMPRSS } 2 \text { Inhibitor }\end{array}$ \\
\hline $\begin{array}{l}\text { aiLUNG + SARS-CoV-2 + JAK } \\
1+2 \text { Inhibitor }\end{array}$ & $\begin{array}{l}\text { Differentiated Infected and } \\
\text { Treated (1 drug) }\end{array}$ & $\begin{array}{l}\text { aiLUNG + viremia + active TMPRSS2 + } \\
\text { JAK } \mathbf{1 + 2} \text { Inhibitor }\end{array}$ \\
\hline $\begin{array}{l}\text { aiLUNG + SARS-CoV-2 + JAK } \\
1+3 \text { Inhibitor }\end{array}$ & $\begin{array}{l}\text { Differentiated Infected and } \\
\text { Treated ( } 1 \text { drug) }\end{array}$ & $\begin{array}{l}\text { aiLUNG + viremia + active TMPRSS } 2+ \\
\text { JAK } 1+3 \text { Inhibitor }\end{array}$ \\
\hline $\begin{array}{l}\text { aiLUNG + SARS-CoV-2 + IFN- } \\
\text { gamma Inhibitor }\end{array}$ & $\begin{array}{l}\text { Differentiated Infected and } \\
\text { Treated (1 drug) }\end{array}$ & $\begin{array}{l}\text { aiLUNG + viremia + active TMPRSS2 + } \\
\text { IFN-gamma Inhibitor }\end{array}$ \\
\hline $\begin{array}{l}\text { aiLUNG + SARS-CoV-2 + } \\
\text { Cathepsin B Inhibitor }\end{array}$ & $\begin{array}{l}\text { Differentiated Infected and } \\
\text { Treated ( } 1 \text { drug) }\end{array}$ & $\begin{array}{l}\text { aiLUNG + viremia + active TMPRSS2 + } \\
\text { Cathepsin B Inhibitor }\end{array}$ \\
\hline $\begin{array}{l}\text { aiLUNG + SARS-CoV-2 + } \\
\text { Cathepsin L Inhibitor }\end{array}$ & $\begin{array}{l}\text { Differentiated Infected and } \\
\text { Treated ( } 1 \text { drug) }\end{array}$ & $\begin{array}{l}\text { aiLUNG + viremia + active TMPRSS2 + } \\
\text { Cathepsin L Inhibitor }\end{array}$ \\
\hline $\begin{array}{l}\text { aiLUNG + SARS-CoV-2 + } \\
\text { PLpro Inhibitor }\end{array}$ & $\begin{array}{l}\text { Differentiated Infected and } \\
\text { Treated ( } 1 \text { drug) }\end{array}$ & $\begin{array}{l}\text { aiLUNG + viremia + active TMPRSS } 2+ \\
\text { PLpro Inhibitor }\end{array}$ \\
\hline $\begin{array}{l}\text { aiLUNG + SARS-CoV-2 + } \\
\text { G-CSF Inhibitor }\end{array}$ & $\begin{array}{l}\text { Differentiated Infected and } \\
\text { Treated ( } 1 \text { drug) }\end{array}$ & $\begin{array}{l}\text { aiLUNG + viremia + active TMPRSS2 + } \\
\text { G-CSF Inhibitor }\end{array}$ \\
\hline
\end{tabular}

OKSM = OCT4, KLF4, SOX2, CMYC; Dox = Doxycycline, IL = Interleukin, COX-2 = Cyclo-oxygenase 2, TNF = Tumor Necrosis Factor, HCQ = Hydroxychloroquine, IFN = Interferon, TMPRSS2 = Transmembrane Serine 
Protease 2, 3CLpro = 3 Chymotrypsin Like protease, JAK = Janus Kinase, RdRP = RNA Dependent RNA Polymerase, PLpro = Papain-Like protease, G-CSF = Granulocyte Colony Stimulating Factor, aiLUNG + SARS-CoV-2 = aiLUNG-COVID-19

Table 2: Summary of evaluated double drug combination simulations

\begin{tabular}{|c|c|c|}
\hline $\begin{array}{l}\text { aiLUNG + SARS-CoV-2 + } \\
\text { coX2 + IL-1a+b Inhibitors }\end{array}$ & $\begin{array}{l}\text { Differentiated Infected } \\
\text { and Treated ( } 2 \text { drug) }\end{array}$ & $\begin{array}{l}\text { aiLUNG + viremia + active TMPRSS2 + } \\
\text { COX2 + IL-1 } a+b \text { Inhibitors }\end{array}$ \\
\hline $\begin{array}{l}\text { aiLUNG + SARS-CoV-2 + } \\
\text { COX2 + IL-6 Inhibitors }\end{array}$ & $\begin{array}{l}\text { Differentiated Infected } \\
\text { and Treated ( } 2 \text { drug) }\end{array}$ & $\begin{array}{l}\text { aiLUNG + viremia + active TMPRSS2 + } \\
\text { COX2 + IL-6 Inhibitors }\end{array}$ \\
\hline $\begin{array}{l}\text { aiLUNG + SARS-CoV-2 + } \\
\text { COX2 + TNFa Inhibitors }\end{array}$ & $\begin{array}{l}\text { Differentiated Infected } \\
\text { and Treated ( } 2 \text { drug) }\end{array}$ & $\begin{array}{l}\text { aiLUNG + viremia + active TMPRSS2 + } \\
\text { COX2 + TNFa Inhibitors }\end{array}$ \\
\hline $\begin{array}{l}\text { aiLUNG + SARS-CoV-2 + } \\
\text { IL-1 a+b + TNFa Inhibitors }\end{array}$ & $\begin{array}{l}\text { Differentiated Infected } \\
\text { and Treated ( } 2 \text { drug) }\end{array}$ & $\begin{array}{l}\text { aiLUNG + viremia + active TMPRSS2 + } \\
\text { IL-1 } \mathbf{a + b}+\text { + TNFa Inhibitors }\end{array}$ \\
\hline $\begin{array}{l}\text { aiLUNG + SARS-CoV-2 + HCQ } \\
+ \text { IL-1a+b Inhibitor }\end{array}$ & $\begin{array}{l}\text { Differentiated Infected } \\
\text { and Treated ( } 2 \text { drug) }\end{array}$ & $\begin{array}{l}\text { aiLUNG + viremia + active TMPRSS2 + } \\
\text { HCQ + IL-1a+b Inhibitor }\end{array}$ \\
\hline $\begin{array}{l}\text { aiLUNG + SARS-CoV-2 + HCQ } \\
+ \text { TNFa Inhibitor }\end{array}$ & $\begin{array}{l}\text { Differentiated Infected } \\
\text { and Treated ( } 2 \text { drug) }\end{array}$ & $\begin{array}{l}\text { aiLUNG + viremia + active TMPRSS2 + } \\
\text { HCQ + TNFa Inhibitor }\end{array}$ \\
\hline $\begin{array}{l}\text { aiLUNG + SARS-CoV-2 + IL-6 + } \\
\text { TNFa Inhibitors }\end{array}$ & $\begin{array}{l}\text { Differentiated Infected } \\
\text { and Treated ( } 2 \text { drug) }\end{array}$ & $\begin{array}{l}\text { aiLUNG + viremia + active TMPRSS2 + } \\
\text { IL-6 + TNFa Inhibitors }\end{array}$ \\
\hline $\begin{array}{l}\text { aiLUNG + SARS-CoV-2 + COX2 } \\
\text { Inhibitor + HCQ }\end{array}$ & $\begin{array}{l}\text { Differentiated Infected } \\
\text { and Treated ( } 2 \text { drug) }\end{array}$ & $\begin{array}{l}\text { aiLUNG + viremia + active TMPRSS2 + } \\
\text { COX2 Inhibitor + HCQ }\end{array}$ \\
\hline $\begin{array}{l}\text { aiLUNG + SARS-CoV-2 + IFN } \\
\mathbf{a}+\mathbf{b}+\text { IL-1 } \mathbf{a}+\mathbf{b} \text { Inhibitors }\end{array}$ & $\begin{array}{l}\text { Differentiated Infected } \\
\text { and Treated ( } 2 \text { drug) }\end{array}$ & $\begin{array}{l}\text { aiLUNG + viremia + active TMPRSS2 + } \\
\text { IFN } \mathbf{a}+\mathbf{b}+\mathbf{I L}-\mathbf{1} \mathbf{a}+\mathbf{b} \text { Inhibitors }\end{array}$ \\
\hline $\begin{array}{l}\text { aiLUNG + SARS-CoV-2 + IFN } \\
\mathbf{a}+\mathbf{b}+\text { TNFa Inhibitors }\end{array}$ & $\begin{array}{l}\text { Differentiated Infected } \\
\text { and Treated ( } 2 \text { drug) }\end{array}$ & $\begin{array}{l}\text { aiLUNG + viremia + active TMPRSS2 + } \\
\text { IFN } \mathbf{a}+\mathbf{b}+\text { TNFa Inhibitors }\end{array}$ \\
\hline $\begin{array}{l}\text { aiLUNG + SARS-CoV-2 + IL-1 } \\
\mathbf{a}+\mathbf{b}+\text { IL-6 Inhibitors }\end{array}$ & $\begin{array}{l}\text { Differentiated Infected } \\
\text { and Treated ( } 2 \text { drug) }\end{array}$ & $\begin{array}{l}\text { aiLUNG + viremia + active TMPRSS2 + } \\
\text { IL-1 } \mathbf{a}+\mathbf{b}+\mathbf{I L}-\mathbf{6} \text { Inhibitors }\end{array}$ \\
\hline $\begin{array}{l}\text { aiLUNG + SARS-CoV-2 + HCQ } \\
\text { + IFN a+b Inhibitor }\end{array}$ & $\begin{array}{l}\text { Differentiated Infected } \\
\text { and Treated ( } 2 \text { drug) }\end{array}$ & $\begin{array}{l}\text { aiLUNG + viremia + active TMPRSS2 + } \\
\text { HCQ + IFN a+b Inhibitor }\end{array}$ \\
\hline $\begin{array}{l}\text { aiLUNG + SARS-CoV-2 + HCQ } \\
\text { + IL-6 Inhibitor }\end{array}$ & $\begin{array}{l}\text { Differentiated Infected } \\
\text { and Treated ( } 2 \text { drug) }\end{array}$ & $\begin{array}{l}\text { aiLUNG + viremia + active TMPRSS2 + } \\
\text { HCQ + IL-6 Inhibitor }\end{array}$ \\
\hline $\begin{array}{l}\text { aiLUNG + SARS-CoV-2 + IFN } \\
\mathbf{a}+\mathbf{b}+\text { IL-6 Inhibitors }\end{array}$ & $\begin{array}{l}\text { Differentiated Infected } \\
\text { and Treated ( } 2 \text { drug) }\end{array}$ & $\begin{array}{l}\text { aiLUNG + viremia + active TMPRSS2 + } \\
\text { IFN } \mathbf{a}+\mathbf{b}+\text { IL-6 Inhibitors }\end{array}$ \\
\hline $\begin{array}{l}\text { aiLUNG + SARS-CoV- } 2 \text { + COX2 } \\
\text { + IFN a+b Inhibitors }\end{array}$ & $\begin{array}{l}\text { Differentiated Infected } \\
\text { and Treated ( } 2 \text { drug) }\end{array}$ & $\begin{array}{l}\text { aiLUNG + viremia + active TMPRSS2 + } \\
\text { COX } 2 \text { + IFN } \mathbf{a}+\mathbf{b} \text { Inhibitors }\end{array}$ \\
\hline
\end{tabular}


The final predictions from the wild type aiPSC and aiLUNG simulations regarding the expression or repression of genes and proteins and presence or absence of phenotypic features were directly validated with published data as outlined previously (6). All experiments in this study were conducted in triplicate $(\mathrm{N}=3)$ using different initial conditions in the form of initial state vectors.

Detailed consensus genotypic and phenotypic profiles for both the cytokine storm and coagulopathy were generated from the peer reviewed literature. These features are summarized in Table 3 below and presented in graphic form in Figures $1 \mathrm{~A}$ and $1 \mathrm{~B}$ to contrast the highly significant differences between aiLUNG and aiLUNG-COVID-19 (two tailed Mann-Whitney u test $P<0.0001$ ).

\section{Table 3}

$\begin{array}{ll}\text { COVID-19 } & \text { Profile Factors } \\ \text { Complications } & \end{array}$

Cytokine Storm factors $(\mathrm{N}=14)$

Coagulopathy factors $(\mathrm{N}=17)$
CRP1, Ferritin, G-CSF, IFNg, IL-2, IL-6, IL-7, IP-10, MCP-1, MIP-1a, TNFa, JAK1, JAK2 and JAK3

CRP1, D-dimer, EPCR, Factor Xa, Fibrin-crosslinked-soluble, Fibrin-insoluble, Fibrinogen, FDPs, PAR, PAR2, ProteinC, ProteinS, Thrombin, IL-1a, IL-1b, IL-6 and TNFa

CRP1 = C-Reactive Protein, G-CSF = Granulocyte Colony Stimulating Factor, IFNg = Interferon gamma, IL= Interleukin, IP-10 = Interferon gamma-induced protein 10, MCP-1 = Monocyte Chemotactic Protein 1, MIP$1 \mathrm{a}=$ Macrophage Inflammatory Protein 1-Alpha, TNFa $=$ Tumor Necrosis Factor alpha, JAK = Janus Kinase, D-dimer $=$ a type of Fibrin Degradation Product, EPCR $=$ Endothelial Cell Protein C Receptor, Factor $\mathrm{Xa}=$ Coagulation Factor Xa, PAR = Proteinase-activated Receptors

\section{DeepNEU platform statistical analysis}

Statistical analysis of DeepNEU simulation predictions vs the published literature used the unbiased binomial test. This test provides an exact probability, can compensate for prediction bias and is ideal for determining the statistical significance of experimental deviations from an actual distribution of observations that fall into two outcome categories (e.g., agree vs disagree). A p-value $<0.05$ is considered significant and is interpreted to show that the observed relationship between simulated and actual unseen wet lab data is unlikely to have occurred by chance alone. The pretest probability of a positive outcome prediction is 0.661 and the pretest probability of a negative prediction is therefore 0.339 . This system bias was used when applying the binomial test to all simulation outcomes. For other between group comparisons the Mann-Whitney u test of significance was used (18). This nonparametric test was chosen because some of the data was not normally distributed.

To evaluate statistical significance and rank the treatment options, we used a multistep analysis of the repurposed single drug and two drug combination data as outlined below. 
Step 1a: First we compared the aiLUNG-WT cell profiles to the aiLUNG-COVID-19 profiles using the MannWhitney u test to establish that these profiles were significantly different from each other.

Step 1b: The Mann-Whitney u test was then used to evaluate which treatment option profiles were significantly different from the aiLUNG-COVID-19 profile. This would result in a form of clustering of the profiles relative to the uninfected aiLUNG profile.

Step 2: The ranking of the predictions began with the calculation of Cosine Similarity (CS) for all interventions based on similarity to the aiLUNG or uninfected profiles. Cosine Similarity is a commonly used measure for comparing the similarity of two or more continuously valued vectors with the same number of elements. As similarity between the vectors increases, CS increases to +1 or maximum similarity. As CS similarity decreases away from the reference vector and becomes increasingly dissimilar, CS decrease towards -1 or maximum dissimilarity(19). We then used a simple mathematical transformation to derive Angular Cosine Distance (ACD) using the formula $A C D=\operatorname{arcosine}(C S) / \mathrm{Pi} . \mathrm{ACD}$ was selected because (1) it conforms with all four properties of a valid distance metric, (2) sample sizes are relatively small $(\mathrm{N}<20)$ minimizing any influence of the curse of dimensionality and $(3)$ it is a widely used and well validated metric for comparing bounded $(-1$ to +1$)$ continuous valued vectors $(20)$.

Step 3: Next, we ranked the cytokine storm and DIC like coagulopathy treatment options separately using the ACD metric.

Step 4: Next, the individual cytokine storm and coagulopathy data were sorted based on alphabetic order of the treatment options so that the two groups would be comparable.

Step 5: We then calculated the average of the ACD metric for cytokine storm and coagulopathy.

Step 6: Finally, the combined cytokine storm and coagulopathy data were sorted on the ACD metric to obtain the final ranking of treatment options that are effective for both cytokine storm and coagulopathy outcomes. All final repurposed drug combinations were selected such that the average ACD metric were greater than the ACD metric of the most effective single agent.

\section{Results}

\section{The aiPSC and wild type (uninfected) aiLUNG simulations}

As reported previously both the unsupervised aiPSC simulations and the unsupervised aiLUNG simulations converged quickly (24 iterations) to a new system wide steady state without evidence of overtraining after 1000 iterations. The aiPSC simulations expressed the same human hESC specific surface antigen and genomic profile as both undifferentiated human embryonic stem cells (hESC) and induced pluripotent stem cells (iPSC) (15). The probability that all $(\mathrm{N}=15)$ of these aiPSC-WT outcomes were correctly predicted by chance alone using the binomial test is 0.0021 . 
The aiLUNG simulations produced similar genotypic and phenotypic expression profiles when compared with the human wild type (ATI and ATII) lung cell specific factors taken from the literature (15). The probability that all $(\mathrm{N}=15)$ of these aiLUNG outcomes were correctly predicted by chance alone using the binomial test is 0.0021 . Importantly, the data also indicate that the generation of aiLUNG cells from aiPSC produces a heterogenous population of alveolar cell precursors and more mature alveolar cells consistent with previous study (21).

Simulation of SARS-CoV-2-infected aiLUNG cells (aiLUNG-COVID-19)

The next step in the experiments was to expose the aiLUNG cells to simulated SARS-CoV-2 virus. For this simulated infection, the concept of SARS-CoV-2 viremia was activated (turned on). The viremia activates the viral life cycle beginning with the interaction of the viral Spike protein with its receptor protein Angiotensin-converting enzyme 2 (ACE2) and ending with exocytosis of new viral particles which completes the cycle by contributing new viral particles to the ongoing viremia (22). The SARS-CoV-2 genome consists of four structural genes, at least 6 non-structural genes and produces at least 10 proteins. The seventeen gene/protein expression profile was compared with the uninfected aiLUNG simulations to assess the validity of simulated COVID-19. All gene/protein factors were expressed/upregulated in the aiLUNG-COVID-19 vs aiLUNG simulations. The probability that all $(\mathrm{N}=17)$ of these aiLUNG-COVID-19 simulation outcomes were correctly predicted by chance alone using the binomial test is 0.0009 .

A phenotypic profile of aiLUNG-COVID-19 was also developed from the published literature and has been described previously(15). These phenotypic features $(\mathrm{N}=8)$ include: New Extracellular Virus release, SpikeACE2 Interface, Spike-RBD, TMPRSS2, Virus Clearance, Virus Intracellular RNA release, Virus Internalization and Virus Replication. The presence of all phenotypic features of COVID-19 was correctly predicted by the aiLUNG-COVID-19 simulations when compared with the aiLUNG simulations. The probability that all $(\mathrm{N}=8)$ of these aiLUNG-COVID-19 outcomes were predicted correctly by chance alone using the binomial test is 0.0364 .

When we combined the genotypic and phenotypic profiles, the probability that all $(\mathrm{N}=25)$ features of simulated aiLUNG-COVID-19 were accurately predicted by chance alone using the binomial test is 0.00003 .

Evaluation of the validated aiLUNG-COVID-19 simulations for repurposing combinations of known drugs that can mitigate COVID-19 associated cytokine storm and coagulopathy

Comparison of the all predictions for $>4100$ factors from the aiLUNG-COVID-19 and aiLUNG simulations revealed a subset of factors that stood out as potential biomarkers. Based on the two tailed MannWhitney u test, the estimated p-values when comparing these aiLUNG-COVID-19 vs aiLUNG factors were highly significant at $p=0.00001$. 
Evaluation of a subset of highly significant factors $(\mathrm{N}=17)$ were selected for further evaluation as previously outlined in(15). Inhibiting each of these factors in an iterative process produced variable effects in COVID-19 associated cytokine storm. Hydroxychloroquine (HCQ) was included in the initial evaluation because (i) it has multiple COVID-19 relevant cellular targets (23) (ii) it is already approved for other indications including malaria and inflammatory diseases, and (iii) early anti-COVID-19 results from at least one small trial appear promising (24). Interestingly, during our initial screening based on genotypic features, HCQ was the only effective single agent capable of significantly decreasing the cytokine storm.

When data from a review of the recent therapeutic literature $(11,19,25-38)$ were used to supplement our data from an extended analysis, ten additional therapeutic candidates were identified. These additional candidates based on a more detailed statistical comparison of aiLUNG vs aiLUNG-COVID-19 include Cathepsins B and L, COX2, IL-1ab, IL-6, Interferon ab, JAKs and TNFa as summarized in Table 4.

\begin{tabular}{|lll|}
\hline New Therapeutic Targets & Mann-Whitney u p value & Target Validation \\
\hline Cathepsin B and L & $<0.0001$ & DeepNEU + Literature \\
\hline COX2 & $<0.0001$ & DeepNEU + Literature \\
\hline IL-1 ab & $<0.0001$ & DeepNEU + Literature \\
\hline IL-6 & $<0.0001$ & DeepNEU + Literature \\
\hline IFN-ab & $<0.0001$ & DeepNEU + Literature \\
\hline JAK1, JAK2 and JAK3 & $<0.0001$ & DeepNEU + Literature \\
\hline TNF-a & $<0.0001$ & DeepNEU + Literature \\
\hline
\end{tabular}

Next, we evaluated this more inclusive group of single drug candidates $(N=16)$ in a second screening run. In the cytokine storm simulations, the most effective single agent from the second screening run was an inhibitor of IL-1 ab followed by inhibitors of IL-6, TNFa, COX2, IFN1 ab and the addition of HCQ, when the output from aiLUNG cells and untreated aiLUNG-COVID-19 simulations were ranked using the ACD metric (Figure 2A). In the experiments with the coagulopathy simulations the most effective single agent was an inhibitor of IL-1 ab followed by inhibitors of IL-6, TNFa, COX2, IFN1 ab and the addition of HCQ (Figure 2B).

Based on these findings a final round evaluating $\mathrm{N}=15$ two drug combinations, was carried out in triplicate. The individual two drug combinations are listed in detail in Table 2 above. Regarding the Cytokine Storm simulations, thirteen of the fifteen two drug combinations evaluated were effective against COVID-19 using the two tailed Mann-Whitney u test based on the 14 viral target profile outlined above. Ranking the effective combinations based on the ACD metric indicate that IL-1ab inhibition was a component of 6 of the effective combinations while TNFa inhibition and HCQ use were each a component of 5 of the effective combinations. Inhibitors of COX 2 and IL- 6 were components of 4 the 
effective the two drug combinations evaluated. Overall, the most effective 2 drug combination for ameliorating the cytokine storm appears to be HCQ plus an inhibitor of TNFa (Figure 3A).

The analysis of the coagulopathy simulations revealed that thirteen of the fifteen drug combinations evaluated were effective in COVID-19 using the two tailed Mann-Whitney u test based on the 17 viral target profile outlined above. A final ranking of these effective combinations based on the ACD metric indicated that TNFa inhibition and IL-1ab inhibition and HCQ application were components of 5 of the effective combinations, while inhibition of COX2 and IL- 6 inhibition were each a component of 4 of the effective two drug combinations evaluated. Overall, the most effective double drug combination for ameliorating the coagulopathy appears to be a COX2 inhibitor plus an inhibitor of IL-1 ab (Figure 3B).

Importantly, we wished to determine which double drug combinations would potentially be most effective against both the cytokine storm and the coagulopathy associated with severe COVID-19. Based on the ACD metric ranking of comparable effective combinations, eight of the two drug combinations ranked above the best of the single drugs for potentially ameliorating both the cytokine storm and the coagulopathy complications. The final ranking based on the average of two ACD metrics indicate that COX2 was a component of four effective combinations while IL-1ab inhibition and HCQ use were each an element of three of the effective combinations. Overall, the most effective double drug combination for ameliorating both the cytokine storm and the coagulopathy appears to be a COX2 inhibitor plus an inhibitor of IL-1 ab followed closely by a combination of either a COX2 inhibitor plus an inhibitor of IL- 6 or HCQ plus a TNFa inhibitor (Figure 4).

Comparing the Efficacy of Single and Double Drug Combinations in Cytokine Storm and Coagulopathy

Finally, we wanted to determine if the data revealed any significant differences in efficacy between single drug and double drug combinations. A comparison of effective drugs and drug combinations indicated that (1) for the cytokine storm simulations the double drug combinations $(\mathrm{N}=13$, average $A C D \pm 95 \% \mathrm{Cl}=$ $0.046 \pm 0.019)$ were generally more effective than single drugs $(\mathrm{N}=7,0.022 \pm 0.005$, two tailed MannWhitney $u$ test $p<0.01)$ and $(2)$ for the coagulopathy simulations the double drug combinations $(N=13$, average $A C D \pm 95 \% \mathrm{Cl}=0.103 \pm 0.008)$ were also generally more effective than single drugs $(N=7,0.167 \pm$ 0.041 , two tailed Mann-Whitney u test $p<0.01$ ).

\section{Discussion}

Previously, we have evaluated the DeepNEU (v5.0) machine learning platform for simulating uninfected (aiLUNG) and SARS-CoV-2 infected differentiated Type 1 (AT1) and Type 2 (AT2) alveolar lung cells (aiLUNG-COVID-19).The primary purpose of this project is to extend our previous research into COVID-19 drug discovery, and to enable the rapid identification of therapeutic targets and drug repurposing specifically for treating both the cytokine storm and coagulopathy frequently seen in patients with severe COVID-19. 
In our recent publication (Esmail and Danter, 2020. Accepted)*, we presented data confirming that the DeepNEU (v5.0) platform can accurately simulate AT1 and AT2 lung cells based on the direct generation of human lung cells (iLUNG) from iPSC that is well documented in the peer reviewed literature $(39,40)$. Importantly, these aiLUNG cells exhibited the same genotypic and phenotypic markers as iLUNG cells that were generated in wet lab experiments (39-41). In addition, when the aiLUNG cells were infected with simulated SARS-CoV-2 the phenotypic $(\mathrm{N}=8)$ and genotypic $(\mathrm{N}=17)$ features of aiLUNG-COVID-19 were all in agreement with the current literature $(2,29,32,39-51)$. When we combined these genotypic and phenotypic profiles, the probability that all $(\mathrm{N}=25)$ features of simulated aiLUNG-COVID-19 were accurately predicted by chance alone using the binomial test is 0.00003 . To summarize, the data from our previous experiments indicated that SARS-CoV-2 viral infection (COVID-19) could be accurately simulated in aiLUNG cells using the DeepNEU (v5.0) machine learning platform (15).

Once the aiLUNG and aiLUNG-COVID-19 simulations were validated against the peer reviewed wet lab research, we applied them to therapeutic target identification and drug re-purposing. In the case of severe COVID-19, no re-purposed therapies are currently approved. The rational evaluation of currently licensed drugs to identify potentially effective therapies or simple double drug combinations may represent the most efficient path to improved patient outcomes when combined with respiratory support plus early and widespread testing.

The use of stem cells (iPSC) for targeted drug discovery has been well reported in the peer reviewed literature (52-54) and our approach to using the aiPSC derived aiLUNG-COVID-19 and aiLUNG simulations for COVID-19 specific drug repurposing has been previously described in detail (15). In the current paper the same approach was used but in this project our drug repurposing efforts were focused specifically on mitigating the cytokine storm and coagulopathy often seen with life threatening COVID-19. As of this writing the only widely available therapies showing promise are the early administration of systemic corticosteroids like dexamethasone and anticoagulation with heparin (55-57)

Evaluating the aiLUNG-COVID-19 simulations for repurposing double drug combinations to mitigate COVID-19 associated cytokine storm and coagulopathy.

We had previously compared all genotypic features for $>4100$ factors from the aiLUNG-COVID-19 and aiLUNG simulations using the two tailed Mann-Whitney u test. A subset of seventeen factors emerged as potential therapeutic targets. This subset of highly significant $(p=0.00001)$ genotypic factors $(N=17)$ were selected for initial evaluation as previously outlined in(15). Inhibiting each of the seventeen factors in an iterative process produced variable effects on COVID-19 associated cytokine storm. As outlined above, the rational for including Hydroxychloroquine (HCQ) in the initial screening run was also proposed and interestingly HCQ was the only agent capable of significantly mitigating the cytokine storm during the initial screening. These significant results indicate that the COVID-19 associated cytokine storm and coagulopathy are more likely to be dependent on the host response to infection than on the SARS-CoV-2 genome itself. Therefore, anti-viral therapy primarily targeting the SARS-CoV-2 genome should not be 
expected to mitigate the cytokine storm and coagulopathy. In established and progressing COVID-19 other targeted approaches will be required (57-60).

To address this probable reality, we carried out a comprehensive review of the recent therapeutic literature to supplement our analysis and identified ten additional therapeutic candidates $(11,19,25-38)$. These new candidates were confirmed by a more detailed statistical analysis of the aiLUNG vs aiLUNG-COVID-19 data and include Cathepsins B and L, COX2, IL-1ab, IL-6, Interferon ab, JAK1-3 and TNFa as summarized above in Table 4. This new data allowed us to evaluate a more extensive group of single drug candidates $(\mathrm{N}=16)$ in a second screening run. In the cytokine storm aiLUNG-COVID-19 simulations the most effective single agent from the second screening run was an inhibitor of IL- 1 ab followed by inhibitors of IL-6, TNFa, COX2, IFN1ab and the addition of HCQ, when the outputs from aiLUNG (uninfected) cells and untreated aiLUNG-COVID-19 simulations were ranked using the ACD metric (Figure 2A). Similarly, the experiments applying the drug candidates to the coagulopathy simulations also identified inhibitors of IL-1ab, IL-6, TNFa, COX2, IFN1ab and the addition of HCQ (Figure 2B). These encouraging results allowed us to proceed with the evaluation of double drug combinations.

Based on these findings a final screening round was carried out to evaluate fifteen double drug combinations. The individual double drug combinations evaluated are presented in detail in Table 2 above. From the cytokine storm simulations, thirteen of the double drug combinations evaluated were effective on the fourteen viral targets profile outlined above. Ranking the most effective combinations according to the Angular Cosine Distance (ACD) from the uninfected profile indicate that overall, the most effective double drug combination for mitigating the cytokine storm is HCQ plus an inhibitor of TNFa as presented in Figure 3A.

The analysis of the coagulopathy simulations also revealed that thirteen of the double drug combinations were effective based on the seventeen viral targets profile outlined above. A final ranking of these effective combinations based on the ACD metric indicated that overall, the most effective double drug combination for ameliorating the Coagulopathy appears to be a COX2 inhibitor plus an inhibitor of IL-1 ab as presented in Figure 3B.

A central purpose of this project was to determine if any double drug combinations could mitigate both the cytokine storm and the coagulopathy associated with severe COVID-19. To that end we ranked the effective combinations based on their ACD metric and determined that seven of the double drug combinations ranked higher than the best of the single drugs based on their potential to alleviate both the cytokine storm and the coagulopathy complications. The final ranking based on the average ACD metric indicated that overall, the most effective double drug combination was a COX2 inhibitor plus an inhibitor of IL-1ab followed closely by a combination of either a COX2 inhibitor plus an inhibitor of IL-6 or HCQ plus an inhibitor of TNFa (Figure 4).

Importantly, all of these effective double drug combinations can be clinically evaluated because the approved drugs are currently available for urgent clinical study. For example, a single specific COX2 inhibitor, namely Celecoxib, is already widely available by prescription in North America. Similarly, HCQ is 
also widely available for use in North America. Although the results from clinical trials exploring the effectiveness of HCQ in preventing or treating COVID-19 have so far been disappointing, combining HCQ with a TNFa inhibitor has not yet been evaluated. Monoclonal antibody inhibitors of TNF including infliximab, adalimumab, certolizumab pegol and golimumab are available and are widely prescribed. Etanercept, a circulating fusion protein TNF receptor inhibitor, is also available. A number of small molecules including thalidomide, lenalidomide and pomalidomide are also active as TNF inhibitors. Anakinra is a recombinant modified version of the human IL-1 receptor antagonist protein that has proven effective in life threatening sepsis and is available for clinical study in severe COVID-19 (31). Available monoclonal antibody inhibitors of IL- 6 include tocilizumab and sarilumab, which are IL-6 receptor inhibitors and siltuximab which targets IL-6 itself.

Comparing the efficacy of single and double drug combinations in cytokine storm and coagulopathy.

Finally, we compared the effectiveness of single drugs and double drug combinations in complicated COVID-19. Our analysis indicated that (1) for the cytokine storm simulations the double drug combinations $(N=13$, average $A C D \pm 95 \% C l=0.046 \pm 0.019)$ were generally more effective than single drugs $(N=7,0.022 \pm 0.005$, two tailed Mann-Whitney u test $p<0.01)$ and (2) similarly for the coagulopathy simulations the double drug combinations $(N=13$, average $A C D \pm 95 \% \mathrm{Cl}=0.103 \pm 0.008)$ were also generally more effective than single drugs $(N=7,0.167 \pm 0.041$, two tailed Mann-Whitney u test $\mathrm{p}<0.01)$.

These results support the conclusion that for serious diseases, drug combinations are generally more effective than single drugs $(61,62)$. With a few exceptions like Gleevec for Chronic Myelogenous Leukemia $(\mathrm{CML})$, this is particularly true in the majority of cancers, in life threatening sepsis and in situations where immune suppression is essential.

We remain aware that predictions from advanced computer simulations still require wet lab confirmation and this continues to be important for DeepNEU v5.0 as well. However, a key aim of this project was to make these findings regarding the potential therapeutic benefit of novel double drug combinations for mitigating the complications of serious COVID-19 freely available to the global research community for wet lab validation at the very earliest opportunity. We also plan to validate these important findings and we are currently looking for development partners with the goal of confirming them in animal models of severe COVID-19. We commit to making any additional information available at the earliest opportunity.

\section{Conclusions/ Significance}

The current results from our continued research and development of the DeepNEU platform have confirmed and extended our previous work(15-17). DeepNEU v5.0 accurately derived aiLUNG cells from aiPSC simulations that could be infected with simulated SARS-CoV-2 virus. These SARS-CoV- 2 infected aiLUNG cells can reproduce the genotypic and phenotypic profile typical of the cytokine storm and coagulopathy that too often complicate severe COVID-19. We also demonstrated that the aiLUNG-COVID19 simulations can be used to rapidly repurpose novel double drug combinations with specific anti- 
COVID-19 therapeutic potential for urgent animal and human trial validation. We also provide evidence that double drug combinations are expected to generally be more effective than single drugs for treating two common complications of severe COVID-19.

We believe it is inevitable that future viral outbreaks will occur and result in potentially lethal complications in large numbers of seriously ill people around the world. The rational process for viral therapeutic target identification and drug repurposing described in this manuscript requires the existence of a validated genome for the viral pathogen(s) in question. Although DeepNEU (v5.0) requires continued development and further validation, it is very likely that the most important application of this machine learning platform will be to improve our preparedness for serious future viral outbreaks and their lifethreatening complications.

\section{Declarations}

Both authors, Dr. Esmail and Dr. Danter, declare that they have no competing interests

\section{AUTHOR CONTRIBUTIONS}

SE and WD conceptualized, and analyzed the experimental work, wrote the manuscript, and prepared the figures. WD performed all computational simulations and sever COVID-19 disease modeling.

\section{References}

1. Organization, W. H. (2021) WHO Corona Virus (COVID-19) Dashboard. World Health Organization Geneva

2. Yang, Y., Peng, F., Wang, R., Guan, K., Jiang, T., Xu, G., Sun, J., and Chang, C. (2020) The deadly coronaviruses: The 2003 SARS pandemic and the 2020 novel coronavirus epidemic in China. Journal of autoimmunity, 102434

3. Tan, C. W., Low, J. G. H., Wong, W. H., Chua, Y. Y., Goh, S. L., and Ng, H. J. (2020) Critically ill COVID-19 infected patients exhibit increased clot waveform analysis parameters consistent with hypercoagulability. American Journal of Hematology

4. Henderson, L. A., Canna, S. W., Schulert, G. S., Volpi, S., Lee, P. Y., Kernan, K. F., Caricchio, R., Mahmud, S., Hazen, M. M., and Halyabar, O. (2020) On the alert for cytokine storm: Immunopathology in COVID-19. Arthritis \& Rheumatology

5. Wang, J., Jiang, M., Chen, X., and Montaner, L. J. (2020) Cytokine storm and leukocyte changes in mild versus severe SARS-CoV-2 infection: Review of 3939 COVID-19 patients in China and emerging pathogenesis and therapy concepts. Journal of leukocyte biology 108, 17-41

6. Mangalmurti, N., and Hunter, C. A. (2020) Cytokine storms: understanding COVID-19. Immunity

7. Chauhan, A. J., Wiffen, L. J., and Brown, T. P. (2020) COVID-19: a collision of complement, coagulation and inflammatory pathways. Journal of Thrombosis and Haemostasis 
8. Wu, C., Chen, X., Cai, Y., Zhou, X., Xu, S., Huang, H., Zhang, L., Zhou, X., Du, C., and Zhang, Y. (2020) Risk factors associated with acute respiratory distress syndrome and death in patients with coronavirus disease 2019 pneumonia in Wuhan, China. JAMA internal medicine

9. Huang, C., Wang, Y., Li, X., Ren, L., Zhao, J., Hu, Y., Zhang, L., Fan, G., Xu, J., and Gu, X. (2020) Clinical features of patients infected with 2019 novel coronavirus in Wuhan, China. The lancet 395, 497-506

10. Li, G., Fan, Y., Lai, Y., Han, T., Li, Z., Zhou, P., Pan, P., Wang, W., Hu, D., and Liu, X. (2020) Coronavirus infections and immune responses. Journal of medical virology $92,424-432$

11. McGonagle, D., O'Donnell, J. S., Sharif, K., Emery, P., and Bridgewood, C. (2020) Immune mechanisms of pulmonary intravascular coagulopathy in COVID-19 pneumonia. The Lancet Rheumatology

12. Terpos, E., Ntanasis-Stathopoulos, I., Elalamy, I., Kastritis, E., Sergentanis, T. N., Politou, M., Psaltopoulou, T., Gerotziafas, G., and Dimopoulos, M. A. (2020) Hematological findings and complications of COVID-19. American journal of hematology

13. Tang, N., Li, D., Wang, X., and Sun, Z. (2020) Abnormal coagulation parameters are associated with poor prognosis in patients with novel coronavirus pneumonia. Journal of thrombosis and haemostasis 18, 844-847

14. Du, F., Liu, B., and Zhang, S. (2020) COVID-19: the role of excessive cytokine release and potential ACE2 down-regulation in promoting hypercoagulable state associated with severe illness. Journal of thrombosis and thrombolysis, 1-17

15. Esmail, S., and Danter, W. (2021) Viral pandemic preparedness: A pluripotent stem cell-based machine-learning platform for simulating SARS-CoV-2 infection to enable drug discovery and repurposing. Stem cells translational medicine 10, 239-250

16. Esmail, S., and Danter, W. R. (2019) DeepNEU: artificially induced stem cell (aiPSC) and differentiated skeletal muscle cell (aiSkMC) simulations of infantile onset POMPE disease (IOPD) for potential biomarker identification and drug discovery. Frontiers in cell and developmental biology 7, 325

17. Danter, W. R. (2019) DeepNEU: cellular reprogramming comes of age-a machine learning platform with application to rare diseases research. Orphanet Journal of Rare Diseases 14, 13

18. Addinsoft. (2019) XLSTAT statistical and data analysis solution. Addinsoft Long Island, New York

19. Paik, H., Chen, B., Sirota, M., Hadley, D., and Butte, A. (2016) Integrating clinical phenotype and gene expression data to prioritize novel drug uses. CPT: pharmacometrics \& systems pharmacology $\mathbf{5}$, 599-607

20. Chanwimalueang, T., and Mandic, D. P. (2017) Cosine similarity entropy: Self-correlation-based complexity analysis of dynamical systems. Entropy 19, 652

21. Li, C., Smith, S. M., Peinado, N., Gao, F., Li, W., Lee, M. K., Zhou, B., Bellusci, S., Pryhuber, G. S., and Ho, H.-Y. H. (2020) WNT5a-ROR Signaling Is Essential for Alveologenesis. Cells 9, 384

22. Shereen, M. A., Khan, S., Kazmi, A., Bashir, N., and Siddique, R. (2020) COVID-19 infection: Origin, transmission, and characteristics of human coronaviruses. Journal of Advanced Research 
23. Li, Z., Qian, Y., Li, W., Liu, L., Yu, L., Liu, X., Wu, G., Wang, Y., Luo, W., and Fang, F. (2020) Human lung adenocarcinoma-derived organoid models for drug screening. Iscience 23, 101411

24. Gautret, P., Lagier, J.-C., Parola, P., Meddeb, L., Mailhe, M., Doudier, B., Courjon, J., Giordanengo, V., Vieira, V. E., and Dupont, H. T. (2020) Hydroxychloroquine and azithromycin as a treatment of COVID19: results of an open-label non-randomized clinical trial. International journal of antimicrobial agents, 105949

25. D'Elia, R. V., Harrison, K., Oyston, P. C., Lukaszewski, R. A., and Clark, G. C. (2013) Targeting the "cytokine storm" for therapeutic benefit. Clinical and Vaccine Immunology 20, 319-327

26. Tay, M. Z., Poh, C. M., Rénia, L., MacAry, P. A., and Ng, L. F. (2020) The trinity of COVID-19: immunity, inflammation and intervention. Nature Reviews Immunology, 1-12

27. Ye, Q., Wang, B., and Mao, J. (2020) The pathogenesis and treatment of theCytokine Storm'in COVID19. Journal of infection $80,607-613$

28. Zhao, M. (2020) Cytokine storm and immunomodulatory therapy in COVID-19: role of chloroquine and anti-IL-6 monoclonal antibodies. International journal of antimicrobial agents

29. Prompetchara, E., Ketloy, C., and Palaga, T. (2020) Immune responses in COVID-19 and potential vaccines: Lessons learned from SARS and MERS epidemic. Asian Pac J Allergy Immuno/ 38, 1-9

30. Thevarajan, I., Nguyen, T. H., Koutsakos, M., Druce, J., Caly, L., van de Sandt, C. E., Jia, X., Nicholson, S., Catton, M., and Cowie, B. (2020) Breadth of concomitant immune responses prior to patient recovery: a case report of non-severe COVID-19. Nature medicine 26, 453-455

31. Mehta, P., McAuley, D. F., Brown, M., Sanchez, E., Tattersall, R. S., Manson, J. J., and Collaboration, H. A. S. (2020) COVID-19: consider cytokine storm syndromes and immunosuppression. Lancet (London, England) 395, 1033

32. Fu, Y., Cheng, Y., and Wu, Y. (2020) Understanding SARS-CoV-2-mediated inflammatory responses: from mechanisms to potential therapeutic tools. Virologica Sinica, 1-6

33. Wang, C., Li, W., Drabek, D., Okba, N. M., van Haperen, R., Osterhaus, A. D., van Kuppeveld, F. J., Haagmans, B. L., Grosveld, F., and Bosch, B.-J. (2020) A human monoclonal antibody blocking SARSCoV-2 infection. Nature communications 11, 1-6

34. Zumla, A., Chan, J. F., Azhar, E. I., Hui, D. S., and Yuen, K.-Y. (2016) Coronaviruses-drug discovery and therapeutic options. Nature reviews Drug discovery 15, 327-347

35. Favalli, E. G., Biggioggero, M., Maioli, G., and Caporali, R. (2020) Baricitinib for COVID-19: a suitable treatment? The Lancet Infectious Diseases

36. Georgiev, T. (2020) Coronavirus disease 2019 (COVID-19) and anti-rheumatic drugs. Rheumatol Int 1

37. Zhu, G., Pan, C., Bei, J.-X., Li, B., Liang, C., Xu, Y., and Fu, X. (2020) Mutant p53 in Cancer Progression and Targeted Therapies. Frontiers in Oncology 10, 2418

38. Guo, Y.-R., Cao, Q.-D., Hong, Z.-S., Tan, Y.-Y., Chen, S.-D., Jin, H.-J., Tan, K.-S., Wang, D.-Y., and Yan, Y. (2020) The origin, transmission and clinical therapies on coronavirus disease 2019 (COVID-19) outbreak-an update on the status. Military Medical Research 7, 1-10

Page $17 / 24$ 
39. Wong, A. P., Shojaie, S., Liang, Q., Xia, S., Di Paola, M., Ahmadi, S., Bilodeau, C., Garner, J., Post, M., and Duchesneau, P. (2019) Conversion of human and mouse fibroblasts into lung-like epithelial cells. Scientific reports $9,1-15$

40. Mitchell, A., Drinnan, C. T., Jensen, T., and Finck, C. (2017) Production of high purity alveolar-like cells from iPSCs through depletion of uncommitted cells after AFE induction. Differentiation 96, 62-69

41. Barkauskas, C. E., Chung, M.-I., Fioret, B., Gao, X., Katsura, H., and Hogan, B. L. (2017) Lung organoids: current uses and future promise. Development 144, 986-997

42. Thevarajan, I., Nguyen, T. H., Koutsakos, M., Druce, J., Caly, L., van de Sandt, C. E., Jia, X., Nicholson, S., Catton, M., and Cowie, B. (2020) Breadth of concomitant immune responses prior to patient recovery: a case report of non-severe COVID-19. Nature Medicine, 1-3

43. Ghaedi, M., Le, A. V., Hatachi, G., Beloiartsev, A., Rocco, K., Sivarapatna, A., Mendez, J. J., Baevova, P., Dyal, R. N., and Leiby, K. L. (2018) Bioengineered lungs generated from human i PSC s-derived epithelial cells on native extracellular matrix. Journal of tissue engineering and regenerative medicine 12, e1623-e1635

44. von Brunn, A., Teepe, C., Simpson, J. C., Pepperkok, R., Friedel, C. C., Zimmer, R., Roberts, R., Baric, R., and Haas, J. (2007) Analysis of intraviral protein-protein interactions of the SARS coronavirus ORFeome. PloS one 2

45. Liu, W., and Li, H. COVID-19: Attacks the 1-Beta Chain of Hemoglobin and Captures the Porphyrin to Inhibit Human Heme Metabolism.

46. Frank, D. B., Penkala, I. J., Zepp, J. A., Sivakumar, A., Linares-Saldana, R., Zacharias, W. J., Stolz, K. G., Pankin, J., Lu, M., and Wang, Q. (2019) Early lineage specification defines alveolar epithelial ontogeny in the murine lung. Proceedings of the National Academy of Sciences 116, 4362-4371

47. Chen, J., Lau, Y. F., Lamirande, E. W., Paddock, C. D., Bartlett, J. H., Zaki, S. R., and Subbarao, K. (2010) Cellular immune responses to severe acute respiratory syndrome coronavirus (SARS-CoV) infection in senescent BALB/c mice: CD4+ T cells are important in control of SARS-CoV infection. Journal of virology 84, 1289-1301

48. Báez-Santos, Y. M., John, S. E. S., and Mesecar, A. D. (2015) The SARS-coronavirus papain-like protease: structure, function and inhibition by designed antiviral compounds. Antiviral research 115 , 21-38

49. Simmons, G., Zmora, P., Gierer, S., Heurich, A., and Pöhlmann, S. (2013) Proteolytic activation of the SARS-coronavirus spike protein: cutting enzymes at the cutting edge of antiviral research. Antiviral research 100, 605-614

50. Rajsbaum, R., and García-Sastre, A. (2013) Viral evasion mechanisms of early antiviral responses involving regulation of ubiquitin pathways. Trends in microbiology 21, 421-429

51. Woo, B., and Baek, K.-H. (2019) Interplay of Deubiquitinating Enzymes and Cytokines. Cytokine \& growth factor reviews

52. Young, W., D’Souza, S., Lemischka, I., and Schaniel, C. (2012) Patient-specific Induced Pluripotent Stem Cells as a Platform for Disease Modeling. Drug Discovery and Precision Personalized Medicine. 
J Stem Cell Res Ther S10, 2

53. Elitt, M. S., Barbar, L., and Tesar, P. J. (2018) Drug screening for human genetic diseases using iPSC models. Human molecular genetics 27, R89-R98

54. Han, C., Chaineau, M., Chen, C. X.-Q., Beitel, L. K., and Durcan, T. M. (2018) Open science meets stem cells: a new drug discovery approach for neurodegenerative disorders. Frontiers in Neuroscience 12, 47

55. Collaborative, C. (2020) Global guidance for surgical care during the COVID-19 pandemic. The British journal of surgery

56. Thachil, J., Tang, N., Gando, S., Falanga, A., Cattaneo, M., Levi, M., Clark, C., and Iba, T. (2020) ISTH interim guidance on recognition and management of coagulopathy in COVID-19. Journal of Thrombosis and Haemostasis 18, 1023-1026

57. Hippensteel, J. A., LaRiviere, W. B., Colbert, J. F., Langouët-Astrié, C. J., and Schmidt, E. P. (2020) Heparin as a Therapy for COVID-19: Current Evidence and Future Possibilities. American Journal of Physiology-Lung Cellular and Molecular Physiology

58. Foley, J. H., and Conway, E. M. (2016) Cross talk pathways between coagulation and inflammation. Circulation research $118,1392-1408$

59. Cao, W., and Li, T. (2020) COVID-19: towards understanding of pathogenesis. Cell Research 30, 367369

60. Jose, R. J., and Manuel, A. (2020) COVID-19 cytokine storm: the interplay between inflammation and coagulation. The Lancet Respiratory Medicine

61. (2017) Rationalizing combination therapies. Nature Medicine 23, 1113-1113

62. Sun, W., Sanderson, P. E., and Zheng, W. (2016) Drug combination therapy increases successful drug repositioning. Drug discovery today 21, 1189-1195

\section{Figures}


A

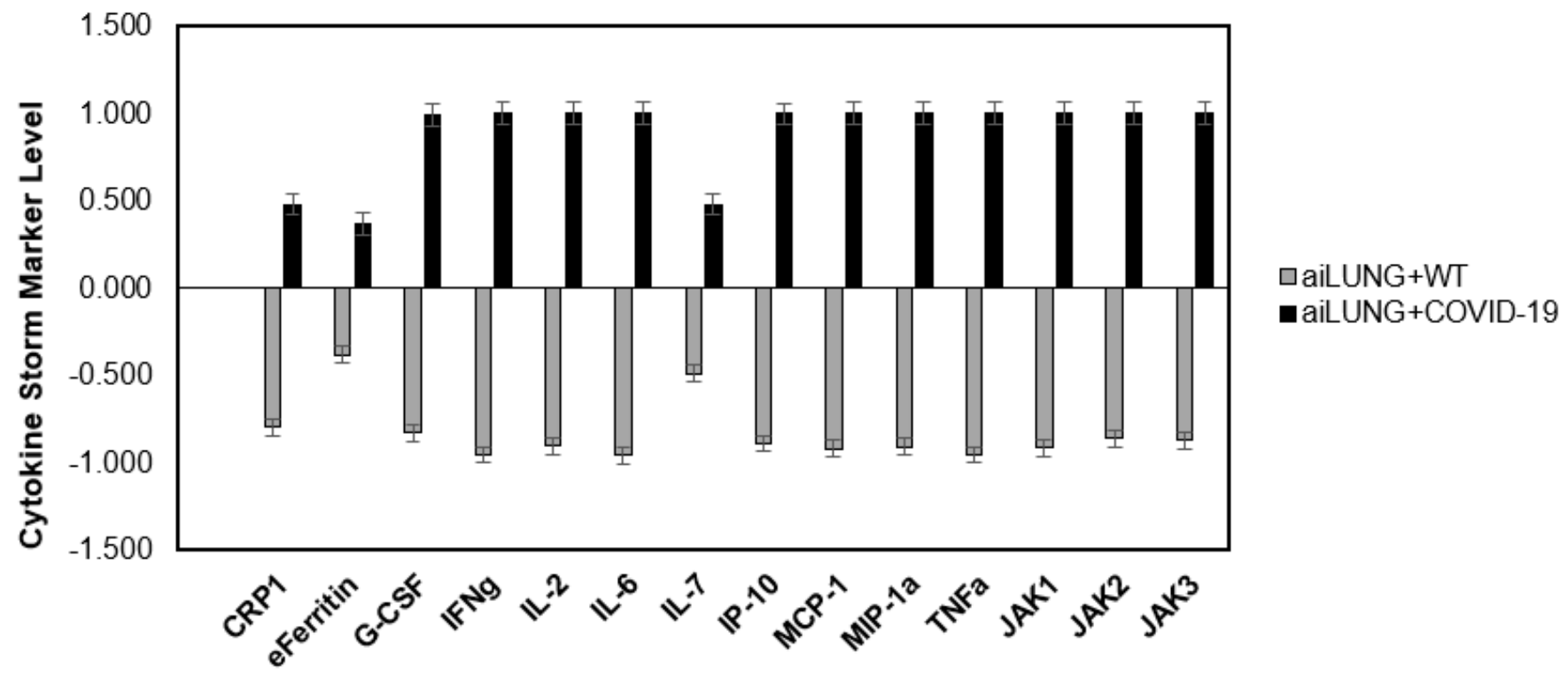

B

Cytokine Storm Markers

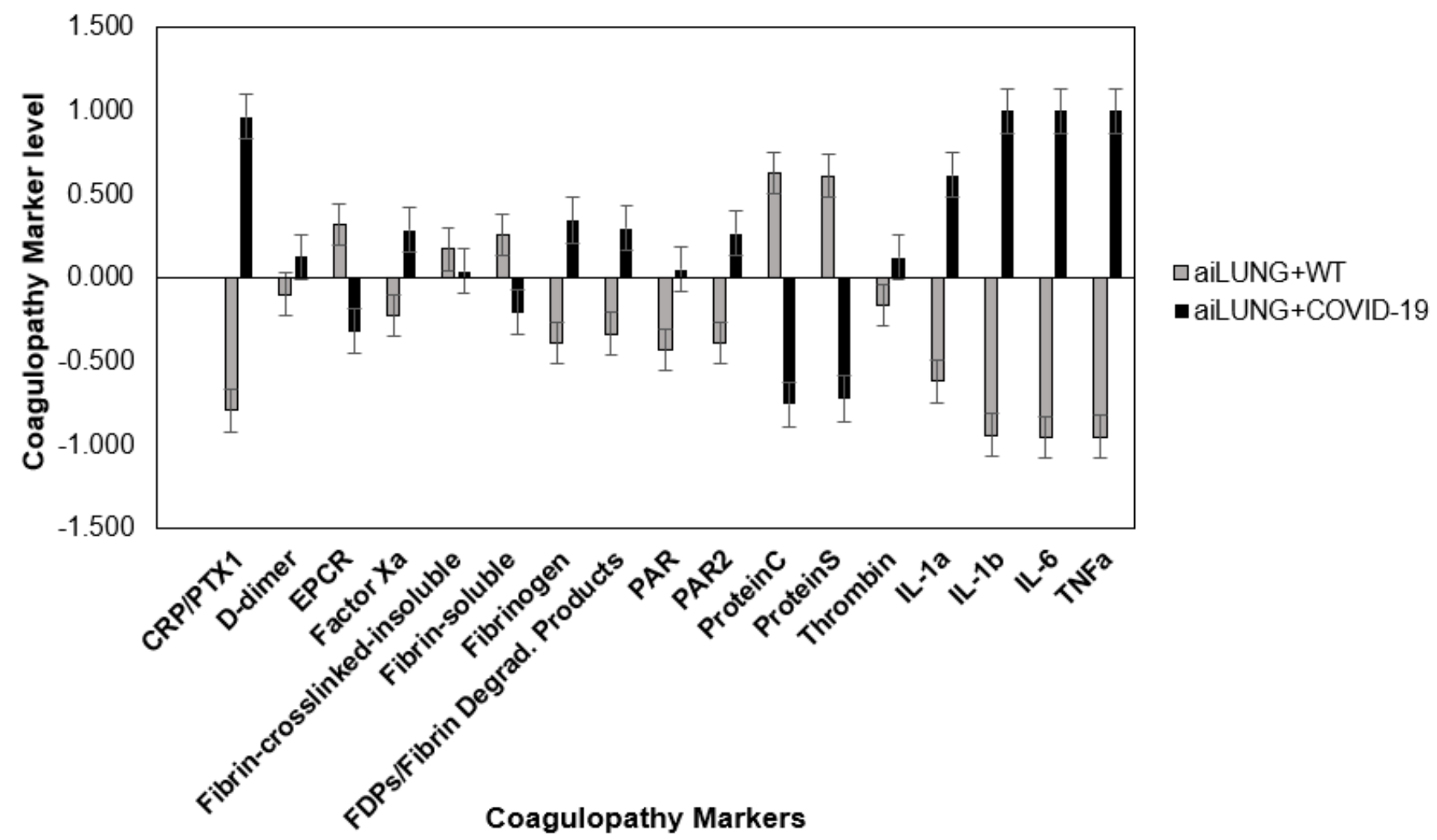

Figure 1

DeepNEU simulations of cytokine storm and coagulopathy in wild type and SARS-CoV-2 infected cells. (A) Expression of cytokine storm markers in differentiated aiLUNG-WT and aiLUNG+COVID-19 cells. (B) Expression of coagulopathy markers in differentiated aiLUNG-WT and aiLUNG+COVID-19 cells. The vertical $(Y)$ axis represents the semi-quantitative levels of cytokine storm and coagulopathy markers that are estimated relative to an arbitrary base line where $0=$ base line, $1=$ maximum expression and $-1=$ 
maximum reduction in expression. The $\mathrm{X}$-axis represents the expression level of each factor relative to the arbitrary baseline. Data represents mean of 3 experiments $\pm 99 \%$ Confidence Interval.

A

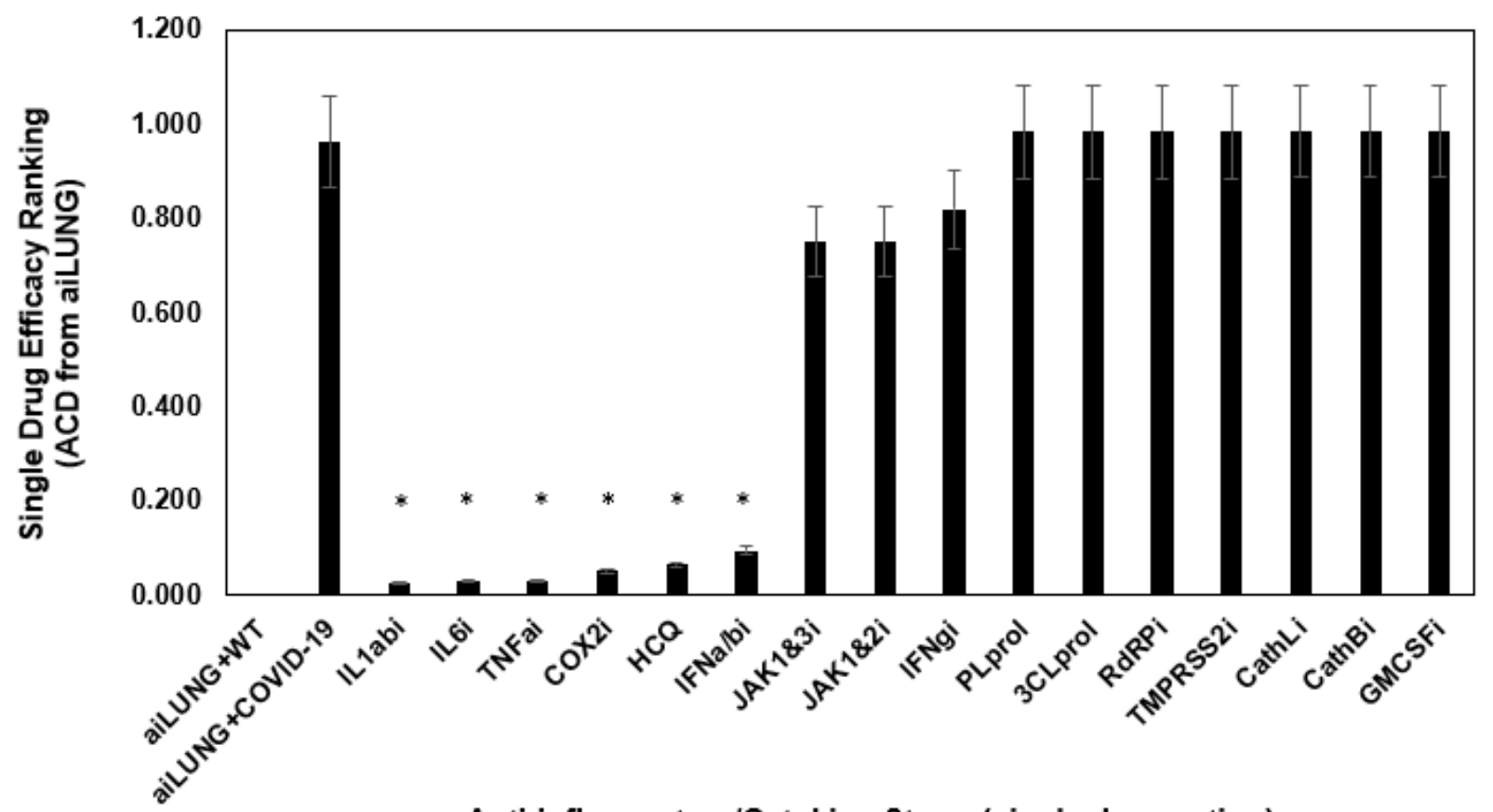

Anti-inflammatory/Cytokine Storm (single drug option)

B

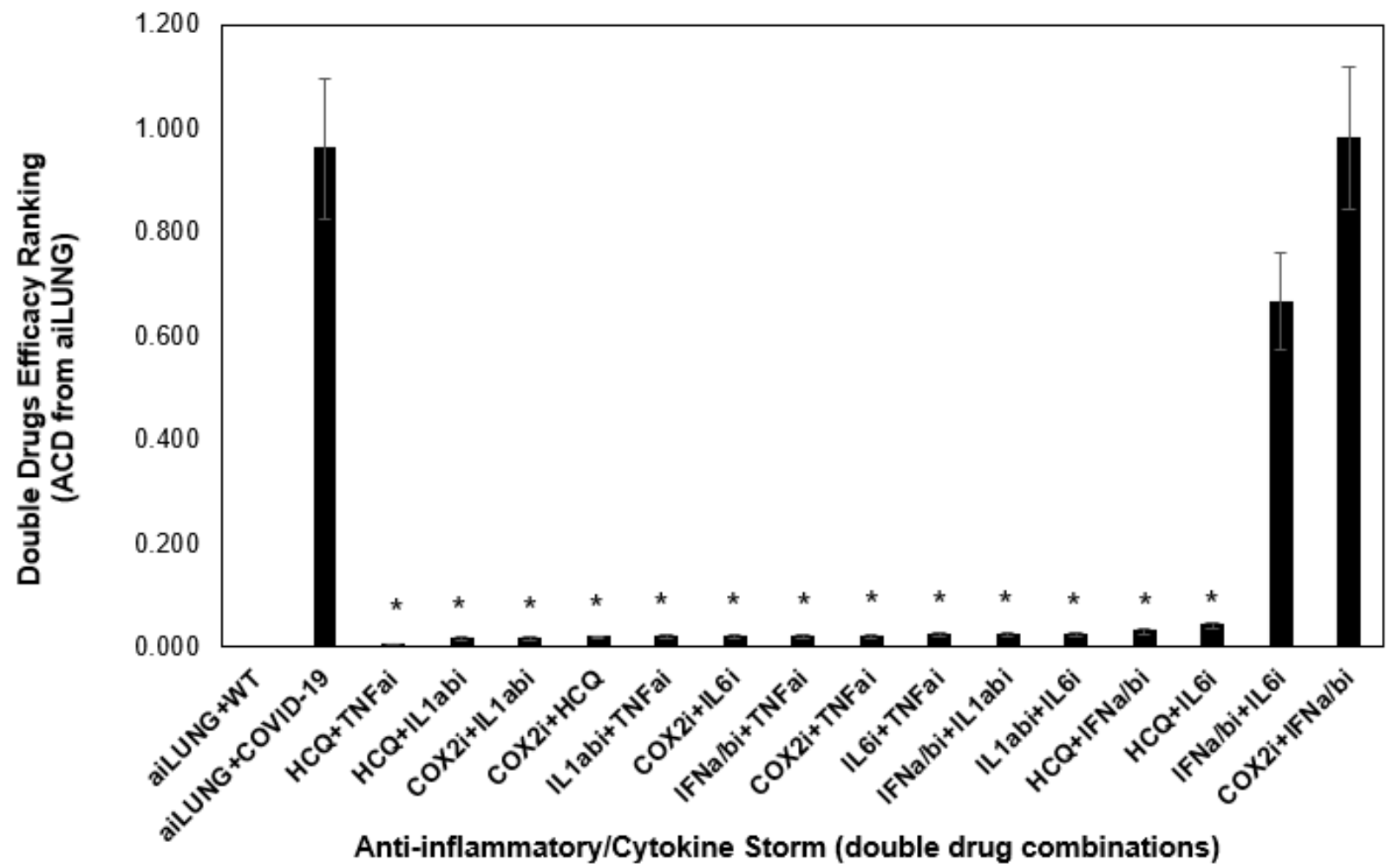

Figure 2

DeepNEU simulations of anti-cytokine storm efficacy (A) Anti-cytokine storm single drug efficacy against aiLUNG+COVID-19 cells. (B) Anti-cytokine storm double drug combinations efficacy against aiLUNG+COVID-19 cells. The vertical (Y) axis represents the single or double drug(s) efficacy based on 
the Angular Cosine Distance (ACD) from aiLUNG-WT. ACDs are calculated such that $0=$ minimal distance and $1=$ maximum distance relative to aiLUNG-WT. More effective treatment options will produce a response closer to aiLUNG-WT (close to 0 ). The X-axis represents the single or double drug combinations evaluated. Data represents mean of 3 experiments $\pm 99 \%$ Confidence Interval. * $p<0.05$

A
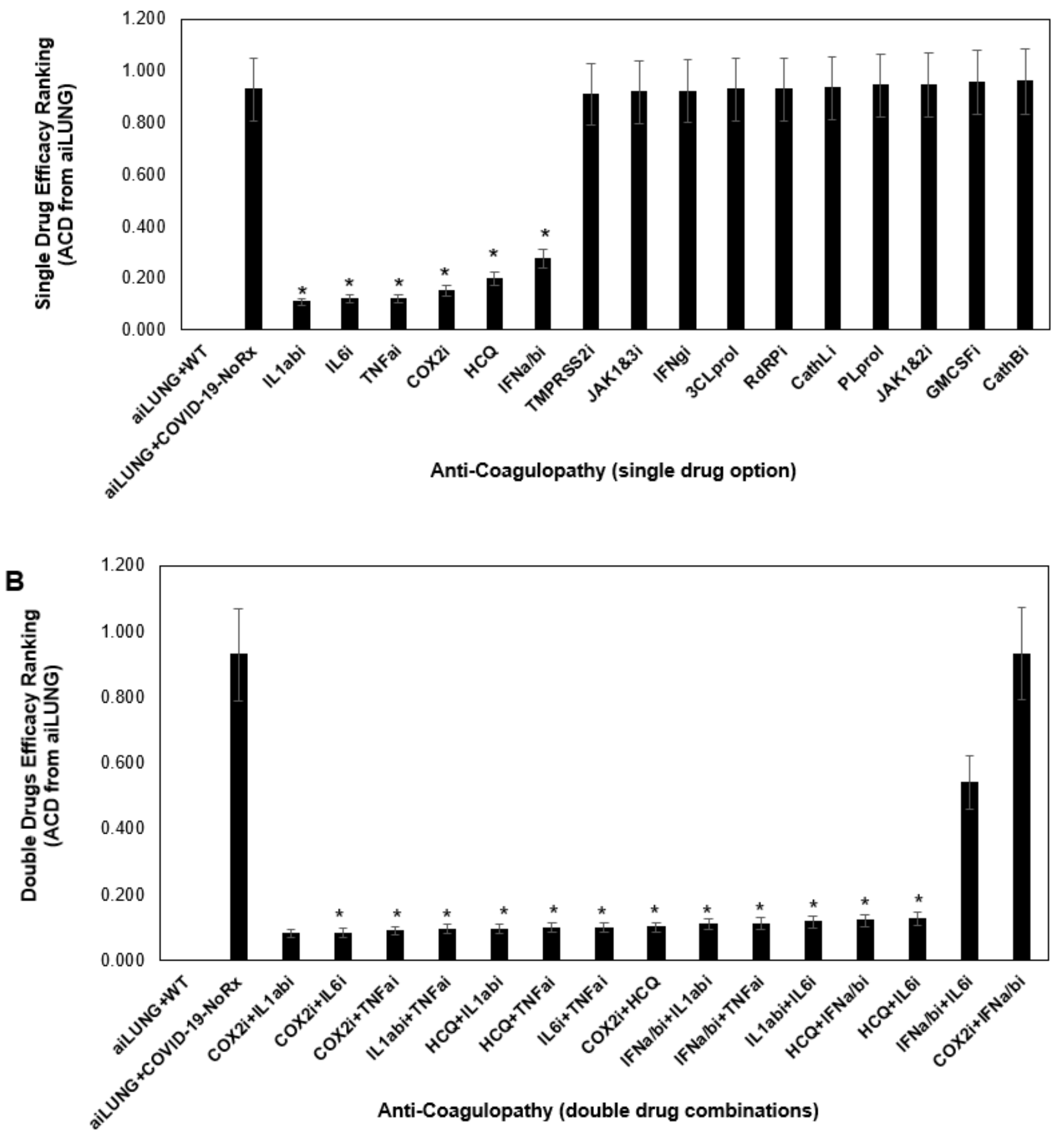

Figure 3 
DeepNEU simulations of anti-coagulopathy efficacy (A) Anti-coagulopathy single drug efficacy against aiLUNG+COVID-19 cells. (B) Anti-coagulopathy double drug combinations efficacy against aiLUNG+COVID-19 cells. The vertical (Y) axis represents the single or double drug(s) efficacy based on the Angular Cosine Distance (ACD) from aiLUNG-WT. ACDs are calculated such that $0=$ minimal distance and $1=$ maximum distance relative to aiLUNG. More effective treatment options will produce a response closer to aiLUNG-WT (close to 0 ). The $X$-axis represents the single or double drug combinations evaluated. Data represents mean of 3 experiments $\pm 99 \%$ Confidence Interval. ${ }^{*} p<0.05$.

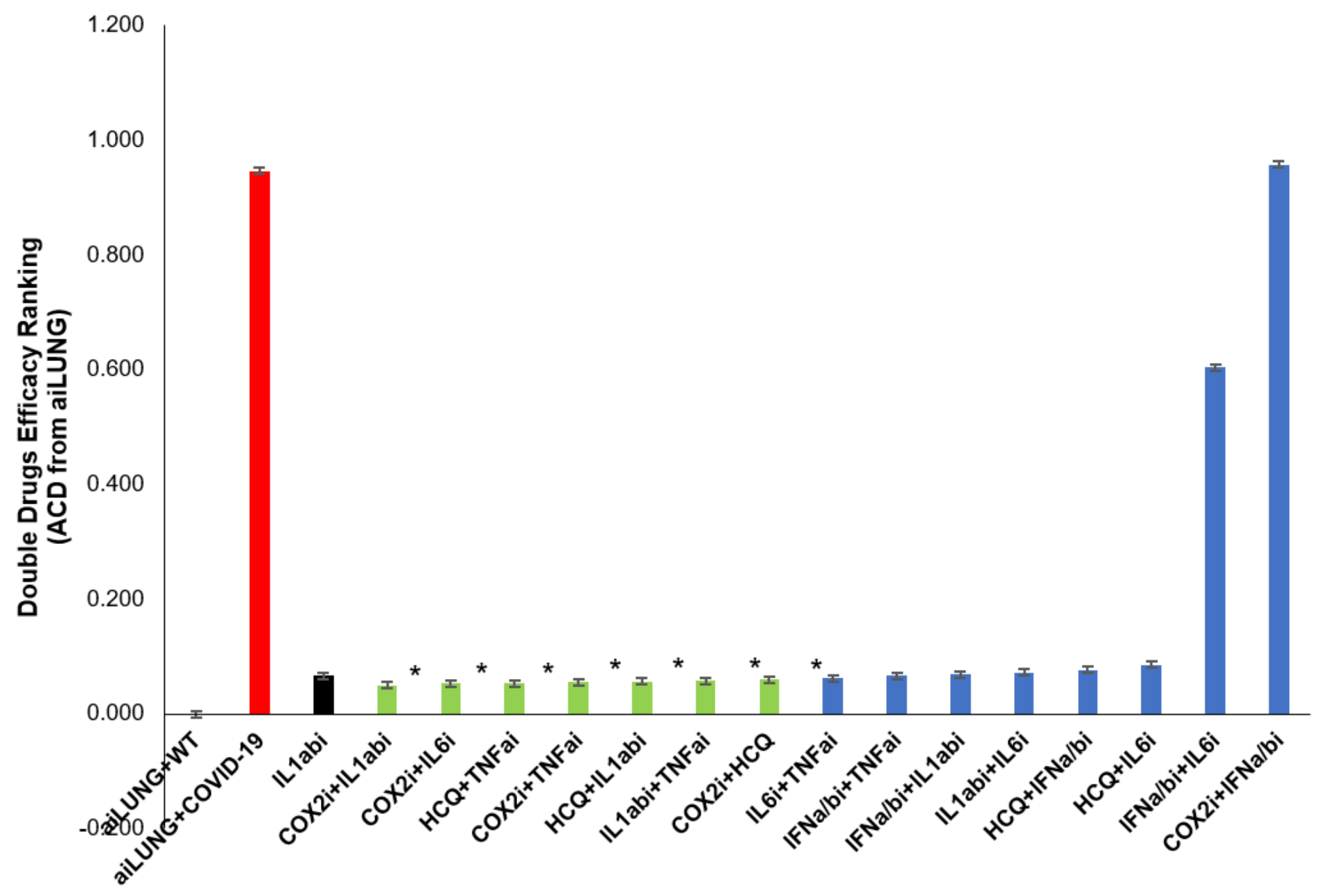

Combined anti-cytokine storm and anti-coagulopathy (double Drug Combinations)

\section{Figure 4}

DeepNEU simulations of combined anti-cytokine storm and anti-coagulopathy efficacy The final ranking of double drug combination efficacy against both the cytokine storm and coagulopathy based on the mean Angular Cosine Distance (ACD) from the most effective single agent, namely an inhibitor of Interleukin 1-ab (IL-1ab). The untreated aiLUNG-COVID-19 simulations (red) had the largest ACD indicating it was the furthest from the aiLUNG-WT profile. The green bars represent the treatment options with ACDs that were significantly below IL-1 $a b(p<0.05)$. Bars in blue represent treatment options that were not significantly different from IL-1 ab. The vertical $(Y)$ axis represents treatment efficacy based on 
the Angular Cosine Distance (ACD) from aiLUNG-WT. ACDs are calculated such that $0=$ minimal distance and 1 = maximum distance relative to aiLUNG-WT. Most effective drug(s) options will produce a treatment response closer to aiLUNG wild type (close to 0 ). The X-axis represents the double drug combinations evaluated $(\mathrm{N}=15)$. Data represents mean of 3 experiments $\pm 99 \%$ Confidence Interval. * $\mathrm{p}<0.05$

\section{Supplementary Files}

This is a list of supplementary files associated with this preprint. Click to download.

- GraphicalAbstract.png 